\title{
Indonesian Tax Reform: Inappropriate Policy Choices or Administrative Problems
}

\author{
Bambang Irawan \\ Department of Public Administration, Administrative Sciences Faculty, Institute of Social Sciences and \\ Management STIAMI, Indonesia (email: bbgirw7980@gmail.com)
}

\begin{abstract}
Purpose -Tax reform in Indonesia has entered a new phase known as the third chapter of reform. This reform has been established out since 2017 and has a target until 2024. The current reform is the biggest in history because it involves changes in the five main pillars, namely organizations, Human Resources, Information Technology and Databases, Business Processes, and Tax Regulations. The purpose of the article is to explore how taxation can accelerate representative democracy and how the tax institution can strengthen the capacity of the government in tax collection. Design/methodology/approach-This article uses a conceptual approach that is rooted in the tax reform, administration, and tax policy literature. Findings - The contribution of this article is twofold. First, it provides a concept of tax reform to accelerate representative democracy by tax administration and policy. Second, this paper examines the policy choices of tax institutions to strengthen the capacity of the government in tax collection. Practical implications - This article helps tax institutions, researchers, and policymakers better understand the implications of tax reform by using appropriate policy choice and tax administration implemented by tax institutions.
\end{abstract}

\section{Keywords:}

Tax reform; tax administration; policy choice

\section{Introduction}

Indonesia's tax ratio which has a downward trend in the last seven years (https://www.pajak.go.id/id/86-rasio-pajak-tax-ratio-dari-masa-ke-masa), explains that there needs to be a change significantly related to the tax position as an instrument of continuous administration and policy improvement. The reform has the intention of a change without damage or to maintain (Irawan, 2014). The reform process is not a radical change and in a short period, but it is a planned and gradual process. Reforms especially in the area of taxation require strong basic assumptions to make changes either administrative or policy. To understand these basic assumptions, several perspectives that make understanding related to tax reform are urgently needed. 
Tax reform in Indonesia has entered the third volume with an orientation on the five pillars of reform, namely Organization, Human Resources, Information Systems and Database, Business Processes and Legislation (https://www.pajak.go.id/id/reformasiperpajakan). Current reforms are more directed towards the need for expansion of government instruments and policy choices as a strategy for carrying out reform programs (Kettle, 2007). From the five pillars above, it can be seen that the Organization, Human Resources, Information Systems and Databases, Business Processes are measures of instrument expansion, while the Laws and Regulations are a form of policy choice.

The purpose of the article is to explore how taxation can accelerate representative democracy and how the tax institution can strengthen the capacity of the government in tax collection. Several perspectives can provide an overview related to tax reform in Indonesia. The perspectives are the State Building perspective, Administrative Reform perspective, and organizational Capacity perspective. Those perspectives are expected to be able to explain the concept of Tax Reform in Indonesia as a whole.

\section{State Building Perspective}

Taxes are not only a source of state revenue, but also encourage efficient allocation of resources, and the process of income redistribution. Taxes play an important role in the country's development process. The role of taxation in developing the country according to Bautigam (2008) is seen in two main areas namely the development of social contracts based on tax agreements, and the development of institutional capacity in gaining revenue. The first role, taxation can encourage regions to realize representative democracy, while the second role is to strengthen the capacity of the state. Both have the potential to increase state legitimacy and increase accountability between the state and its citizens.

There are two concepts related to tax reform from the perspective of state-building, namely tax and policy institutions (Kopric and Hellmut, 2018) First, the concept of tax reform can accelerate representative democracy with tax administration and policy. Second, the reform also discusses the Tax Agency's policy choices in strengthening the government's capacity in tax collection. This has implications for increasing the understanding of all stakeholders regarding tax reform related to the use of tax administration policy choices implemented by a representative and capable Taxation Agency. 


\section{Administrative Reform Perspective}

Irawan (2014) developed the concept of Hahn-Been Lee (1976) which categorizes administrative reforms into three groups. First, procedural reforms that aim to improve public order, in the form of procedural reforms by designing routine government procedures to carry out development. This reform aims to create and ensure a more stable society. Second, technical reforms aimed at improving administrative settlement techniques that were previously in force, which can better respond to the pressures or stimuli of the organization's environment. The motivation of external stimuli could be due to intellectual curiosity over the new method or because of the motivation of power. These more modern administrative reform techniques are used to encourage the modernization process. Third, programmatic reforms aimed at improving administrative performance are implemented through a reform strategy of government programs. In contrast to administrative reforms that are procedural and technical, the focus of programmed or planned reforms is to improve the substance of administration.

There are at least two concepts of tax reform from the perspective of administrative reform. First, technical taxation reforms related to improving the ease of procedure for fulfilling tax obligations or in other words related to tax administration (OECD, 2018). Second, programmed tax reform related to taxation policy determination and the program supporting its policy implementation (Breuer and Kinda, 2018). These two concepts can complement each other in developing a more adaptive and sustainable tax reform strategy.

\section{Organizational Capacity Perspective}

The ability of the organization can be explained from its capacity to describe the achievement of goals, learning, and problem-solving. According to Irawan (2016a) There are three levels in understanding organizational capacity, which comprise micro, meso and macro level. At the micro-level, organizations focus on the individual and the group which oriented towards providing professional resources and techniques. At the meso-level, the organization focusing on management systems for seeking performance improvement in specific tasks and functions. At the macro level, capacity development directed the ability in 
created the rules of the game to respond to the needs about the value of efficiency, effectiveness, responsiveness, fairness, participation, and sustainability that includes support for environmental and regulatory.

Tax reform related to the capacity of the state, especially the institution where the tax reform is run (Pricard, 2010). By using the understanding of capacity level, it will help to find the important things of tax reform determinants. If the capacity level in micro, meso and macro can be explored well, tax policy and administration will adopt the right options to be chosen and a solution to be solved.

\section{Design/Methodology/Approach}

This article used a conceptual approach. This Conceptual analysis is different from empirical analysis because it is neither true nor false but more or less useful for research and communication with other scholars. This does not mean that anyone is free to define terms arbitrarily, without explanation or justification, just by declaring it useful (Baldwin, 2016).

This article uses a conceptual approach that is rooted in tax reform, administration, and tax policy literature. The conceptual analysis presented in this article adopts a threedimensional model for the discussion of tax reform. The first dimension focuses on tax reform basic nature, purpose, and history, as well as the current state and limitations of concepts in accelerate representative democracy by tax administration and policy. The second dimension focuses on policy choices of tax institution to strengthen the capacity of the government in tax collection. This article adopts an interpretive, and conceptual approach to the notion of the tax reform by reviewing the literature and by analyzing the. It proposes a simplified conceptual model for an easy understanding of reform in taxation.

\section{Tax Policy and Tax Administration in Accelerating Representative Democracy}

\section{Tax Policy Design}

Implementation of tax reform based by looking at tax reform from a public finance perspective is an important value (Bird et al., 2004). In this perspective, tax reform is not only viewed by efficiency and international tax best practices but also by equity and potential tax revenue. Taxes are efficient if efficiency-enhancing tax reforms may at the same time face efficiency drawbacks which create obstacles to their effective implementation. The 
impact of tax reform can be explained by tax ratio, as well as a ratio of a nation's tax revenue relative to its Gross Domestic Product (GDP). In 2018, Indonesian tax ratio are still lower relative to other emerging economies country below (Figure 1).

Figure 1.

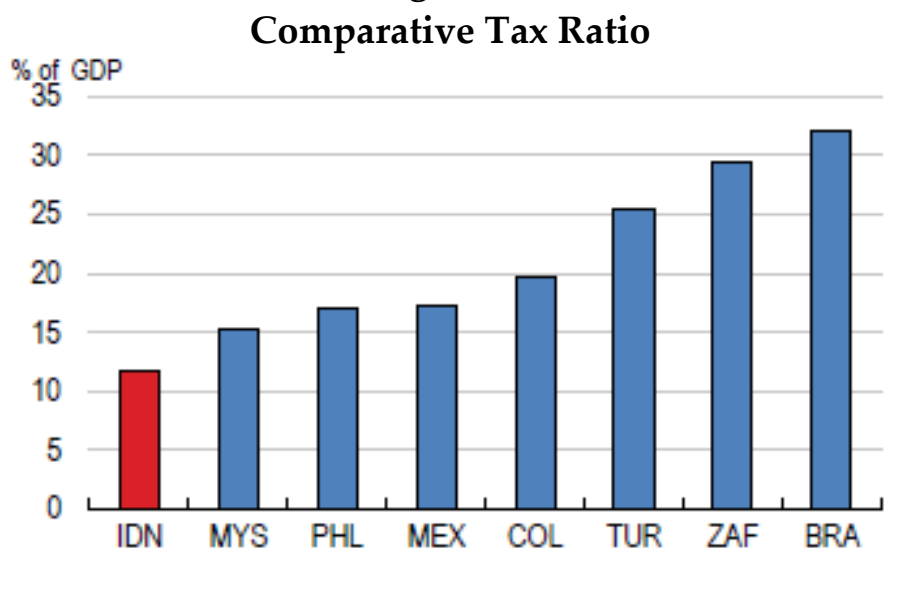

Source: OECD, 2018

There are several types of tax policies which are designed to accelerate representative democracy. The first policy design is reducing personal income tax rates for the employee with lower-income tend to increase labor participation by cut the personal income tax (OECD, 2010). According to Regulation of Financial Ministery Number 101/PMK.010/2016, since 2016 for personal income until Rp. 54.000.000,- in a year, the taxpayer did not necessary to pay tax, addition Rp. 4.500.000,- for married people, and Rp. 4.500.000,- for each kid or parents maximum for 3 persons that relate to the taxpayer. The second policy is a reduction in the corporate income tax rate which increases economic growth. Government Regulation Number 23 in 2018 for Small Medium Enterprise is a sample policy for the reduction. In this regulation, corporate with turnover until Rp. 4.800.000.000,- may use tariff $0.5 \%$, lower than tariff before $1 \%$. This tax incentive will implement in four to seven years depends on types of corporates

\section{Tax administration issues}

Tax reform impacts on the tax administration itself. Tax reform was first carried out in 1983 by changing the taxation system that was originally an official assessment into a self- 
assessment. There are four main pillars related to tax administration, they are organization, Information Technology and database, human resources, and business process perspectives. Each pillar has programs that must be achieved in 2017-2020. These pillars has these pillars are expected to encourage increased tax revenue of 14\% in 2018, higher than in 2017 about only $4 \%$.

Table 1.

Tax Revenue 2015-2018

\begin{tabular}{|l|c|c|c|c|}
\hline Indicator & 2015 & 2016 & 2017 & 2018 \\
\hline Tax Revenue & Rp. $1,060 \mathrm{M}$ & Rp. 1,105 M & Rp. 1,151 M & Rp. 1,313 M \\
\hline Achievement & $81.9 \%$ & $81.6 \%$ & $89.7 \%$ & $92.2 \%$ \\
\hline
\end{tabular}

Source: Accountability and Performance Report of Directorate General of Tax, 2016-2018

From an organizational perspective, reform will make major changes in the tasks performed by the tax administration. The organizational structure adapted the need for taxpayer and tax environment (Fabac, 2010). At present, the number of offices operating more than 500 units and quantities employees of more than 50,000 people spread throughout Indonesia (Accountability and Performance Report of Directorate General of Tax, 2018). Concrete work program covers redesign of organization, employer formation, and taxpayer management to increase low compliance.

Information technology and database is an important aspect in administration (Bourgeois, 2014). Its focus of tasks includes identification of taxpayers, the calculation of the tax liabilities, the provision of assistance and the enforcement of the tax laws. Programs that become references include reducing tax administration costs, expand and accurate database, reliable data processing, and insufficient infrastructure of information systems.

In the human resource perspective, the tax administration also focuses on the training of officials and the development of new compliance monitoring systems. On the other side the quantity of human resources is not proportional to the growth in the number of taxpayers. In 2018, the number of employees is more than 39,000 people which is spread all over the country. Directorate General of Taxes is the largest directorate in Ministry of Finance (Accountability and Performance Report of Directorate General of Tax, 2018).

In business process perspectives, a lot of face to face interaction has been replaced by electronic services. The purposes of this pillar are making a simple, effective, efficient and 
accountable business process, and based on information technology (Gelinas Jr. et al., 2008). These services delivered by using applications in computers or smartphones like e-filling, espt, and e-nofa. The following is a table for the development of taxpayer compliance using efiling in its tax report. Not achieving the target is caused by a significant increase in the number of taxpayers but not accompanied by the ability to report taxes electronically.

Table 2.

Tax Compliance of e-Filing Report 2016-2018

\begin{tabular}{|l|c|c|c|}
\hline Indicator & 2016 & 2017 & 2018 \\
\hline e-Filing & $120 \%$ & $85.72 \%$ & $85.55 \%$ \\
\hline
\end{tabular}

Source: Accountability and Performance Report of Directorate General of Tax, 2016-2018

\section{Tax Institution Capacity in Tax Collection}

A strong tax administration is a condition to ensure high compliance effectively and manage tax policies efficiently. Good tax administration requires strong technical capacity supported by well-designed taxes (WHO, 2011). As public service providers, three types of organizational capacities must be a concern for tax institutions. The three types of capacities in the organization include technical, managerial, and institutional capacity. (Irawan, 2016b).

Organizational structure, technology, and human resources are some form of organizational technical capacity. Business processes are the organizational managerial capacity, while tax policy is the institutional capacity of the organization. Those capacity of the tax institution in collecting taxes related to the technical, managerial and institutional capacity of the organization. The link among scope of reform, pillars of reform and organizational capacity can be seen in the following table:

Table 3.

Scope of Reform, Pillars of Tax Reforms, and Organizational Cpacities

\begin{tabular}{|c|c|c|}
\hline Scope of Reform & Pillars of Tax Reform & Organizational Capacities \\
\hline \multirow{3}{*}{ Tax Administration } & Organization structure & \multirow{2}{*}{ Technical } \\
\cline { 2 - 3 } & Technology & \\
\cline { 2 - 3 } & Human Resource & Managerial \\
\cline { 2 - 3 } & Business Process & Institutional \\
\hline Tax Policy & Tax Policy & \\
\hline
\end{tabular}

Bourgeois (2014), Gelinas Jr. et al. (2008), 


\section{Conclusions and Implications}

This article explored the tax reform in two main explanations. First, tax reform by using appropriate policy choice and tax administration implemented by tax institutions are two inseparable components. Failure to establish appropriate policies and supporting tax administration in carrying out the tax function are two different things but must run together. Second, the form of organizational capacity that can increase the capacity of the government in collecting taxes, adjusted to the level of existing capacity.

The implications for research in tax reform, without two components of tax policy and administration, tax reform will not run well. Kinds of organizational capacity explain that the problems faced in tax collection can be resolved according to the level of organizational capacity.

\section{References}

Baldwin, D.A. (2016), Power and international Relations, A Conceptual Approach, Princeton University Press, New Jersey

Bautigam, D.A. (2008), Introduction: taxation and state-building in developing countries, in Brautigam D.A., Odd-Helge F., Mick M., (Eds.), Taxation and State-Building in Developing Countries, Capacity and Consent, Cambridge University Press, Cambridge, pp. 1-33

Bird, R. M., Martinez-Vazquez, J. and Torgler, B. (2004) Societal Institutions and Tax Effort in Developing Countries. International Studies Program Working Paper 0406. Atlanta, GA, Andrew Young School of Policy Studies, Georgia State University

Bourgeois, D.T. (2014), Information Systems for Business and Beyond, Saylor Academy, Washington DC

Breuer, L.E., Kinda,T. (2018), Realizing Indonesia's Economic Potential: An Overview in Breuer, L.E., Guajardo, J., Kinda, T., (eds.), Realizing Indonesia's economic potential, International Monetary Fund, Washington DC, pp. 3-20

Direktorat Jendral Pajak (2016). Accountability and Performance Report of Directorate General of Tax (LAKIN DJP). Retrived from https://pajak.go.id/sites/default/files/2019-04/LAKIN\%20DJP\%202016.pdf 
Direktorat Jendral Pajak (2017). Accountability and Performance Report of Directorate General of Tax (LAKIN DJP). Retrived from https://www.pajak.go.id/sites/default/files/2019-03/LAKIN\%20DJP\%202017.pdf.

Direktorat Jendral Pajak (2018). Accountability and Performance Report of Directorate $\begin{array}{llllll}\text { General of } & \text { Tax } & \text { (LAKIN } & \text { DJP). } & \text { Retrived }\end{array}$ https://www.pajak.go.id/sites/default/files/2019-05/LAKIN\%20DJP\%202018.pdf

Fabac, R. (2010), Complexity in Organizations and Environment - Adaptive Changes and Adaptive Decision-Making, Interdisciplinary Description of Complex Systems Vol. 8, No. 1, pp. $34-48$

Gelinas Jr., U.J., Sutton, S.G., Federowicz, J.,. (2008), Business Processes and Information Technology, Jacob Fundation, Zurich

Irawan, B. (2014), Reformasi Administrasi dan Karakter Bangsa : Sebuah Kajian Konseptual, Jurnal Transparansi, Vol. 6, N. 2, pp. 109-114

Irawan, B. (2016a). Organizational Capacity Development to Respond to Social Services for Homeless Children, Indian Journal of Science and Technology, Vol. 9, No. 38, pp. 1-5 Irawan, B. (2016b). Kapasitas Organisasi dan Pelayanan Publik, Publica Press, Jakarta

Kettle, D. (2007), The Material Background, in Howard M. and David R., (eds.), Revisiting Dwight Waldo's Administrative State: Constancy and Change in Public Administration's Political Theory, Georgetown University Press, Washington, pp. 15-34.

Koprić, I. Hellmut W. (2018), Evaluating Reforms of Local Public and Social Services in Europe, in Koprić, I., Hellmut, W., Gérard, M., (Eds.), Evaluating Reforms of Local Public and Social Services in Europe, More Evidence for Better Results, Palgrave Macmillan, Cham, pp. 1-18

OECD (2018), OECD Economic Surveys: Indonesia, OECD Publishing, Paris OECD (2010), Tax Policy Reform and Economic Growth, OECD Publishing, Paris Prichard W. (2010). Taxation and State Buliding: Toward a Government focused Tax Reform Agenda. Working Paper 341. Brighton, UK, Institur of Development Studies WHO (2011), WHO Technical Manual on Tobacco Tax Administration, WHO Press, Geneva 